\title{
JPEB
}

Jurnal Penelitian Ekonomi dan Bisnis, 5 (2), 2020, Hal: 152-161

http://www.jpeb.dinus.ac.id

\section{THE EFFECT OF CREDIT RISK AS A MEDIATOR BETWEEN LIQUIDITY AND CAPITAL ADEQUACY ON BANK PERFORMANCE IN BANKING COMPANIES LISTED ON THE IDX}

\author{
Julia Safitri', Ana Kadarningsih²*, Maaz Ud Din ${ }^{3}$, Sri Rahayu ${ }^{4}$ \\ ${ }^{1}$ Sekolah Tinggi Ilmu Ekonomi IPWI Jakarta \\ ${ }^{2}$ Management Study Program, Faculty of Economics and Business, Dian Nuswantoro \\ University \\ Jalan Nakula I No. 5-11 Semarang, Indonesia \\ ${ }^{3}$ Departement of Management Sciences University of Swabi KP-Pakistan \\ ${ }^{4}$ Management Study Program, Faculty of Economics and Business, Budi Luhur University \\ *Corresponding Author: ana.kadarningsih@dsn.dinus.ac.id
}

Received: February 2020; Revised: July 2020; Published: September 2020

\begin{abstract}
Liquidity is one of the main factors faced by banking companies because its main relationship is channeling funds from third parties with bank performance. This study aims to examine credit risk which is proxied by Raroc (return adjusted on risk capital) as a mediator of the effect of liquidity (loan to deposit ratio) on the bank performance (return on assets). The analytical tool used in this study is SEM-WarpPLS 5.0, this study shows that credit risk can mediate the effect of liquidity on bank performance. This shows that the greater the credit risk, the smaller the bank's performance.
\end{abstract}

Keywords: Financial Intermediation Theory; Liquidity; Bank Performance. 


\section{INTRODUCTION}

Banks can be defined through their functions in the economy, services offered to customers and their existence in law. A bank is an intermediary institution that collects funds from the public in the form of deposits and channels them back to the public in the form of credit or other forms to accelerate the overall economic growth of a country. Banking in developing countries has become one of the institutions that play a very important role in domestic economic activities because it becomes one of the sources of funds needed for domestic market activities when other funding sources such as the capital market are still weak and limited and have not been able to provide adequate funding sources for economic activity and investment (Saci et al., 2009).

An important objective of the LDR calculation is to find out and assess how far the bank has a health condition in carrying out its operations or business activities. In other words, LDR is used as an indicator to determine the level of vulnerability of a bank. Some theories related to liquidity management include: Commercial loan theory: the theory emphasizes that banks should only provide loans or short-term loans that are productive and can have the ability to repay loans (self-liquidating) Shiftability theory, this theory is based on the ability a bank to exchange one form of wealth with another form to fulfill its liquidity. The doctrine of anticipated income, according to this theory, it is important that the loan will be paid back or it will not be determined by the income that is expected to be obtained from activities that are either directly financed with the loan or indirectly.

Marozva (2015) stated that LDR is the financial ratio of banking companies related to liquidity aspects. LDR is a traditional measurement that shows time deposits, current accounts, savings, etc. That are used in fulfilling customers' loan requests. This ratio is used to measure the level of liquidity. A high ratio shows that a bank lends all of its funds (loan-up) or is relatively illiquid (illiquid). Conversely, a low ratio indicates a liquid bank with excess capacity of funds that are ready to lend (Vuong Thao Tran, 2016). To achieve its goal of serving its customers and making profits, banks must create a policy of public liquidity (Handorf, 2014). Liquidity illustrates the level of ability of a bank in fulfilling requests / withdrawals of depositors. The maximum liquidity of course can be obtained by banks by holding all activities in the form of cash. This method is certainly not correct because if all assets are in cash, there is no credit or investment, even though the bank also still incurred funds and other operating costs and the bank must cover these costs. Olagunju et al. (2012), Cornett et al. (2011) if a bank's liquidity level is high, the profitability level will decrease. Conversely, if the bank experiences a low level of liquidity, it will cause an increase in the level of profitability. Some research results show the effect of LDR on ROA is significantly positive where the LDR increases, the ROA will increase (Jara-Bertin et al., 2014), (Ahmad, 2016).

An assessment of the capital ratio that is commonly used to measure the health of banks is the Capital Adequacy Ratio (CAR) which is based on the ratio of capital to Risk-Weighted Assets (ATMR), as stipulated in Bank Indonesia Directors Decree Number 26/20 / KEP / DIR concerning Obligations Minimum Capital Supply (KPPM) and Bank Indonesia Circular Letter Number 26/2 / BPPP concerning Minimum Capital Requirements. With the increase in own capital, bank health related to the capital ratio (CAR) will increase. Since the crisis period until now the CAR has become the main reference in determining bank health (BI Dir Decree of 
April 1999), where one API program is to require the minimum capital for commercial banks (including BPD) to be 100 billion with a minimum CAR of $8 \%$ no later than the year 2010 .

CAR is a capital ratio that shows the ability of banks to provide funds for business development needs and to accommodate the risk of loss of funds caused by bank operations. CAR shows the extent to which a decline in bank assets can still be covered by available bank equity (Taswan, 2010). The higher CAR, the more capital owned by banks to cover the decline in assets. CAR is a capital ratio that shows the ability of banks to provide funds for business development needs and to accommodate the risk of loss of funds caused by bank operations. CAR indicates the extent to which a decline in bank assets can still be closed by the available Equity bank, the higher the CAR the better the condition of a bank (Gambacorta and Shin, 2016).

Credit risk is a risk that promises cash flow from loan income and other securities owned by financial institutions that may not be fully paid. The credit risk is very dominant in the composition of the capital adequacy ratio (capital adequacy ratio), where $70 \%$ of capital is allocated for credit risk and 30\% of market risk and operational risk. Thus credit risk is the main cause of bank failures and risk is most visible in the face of bank managers (Garr, 2013). Based on Law No.10 of 1998, it is said that the amount of credit distribution depends on the number of third party funds that can be collected by banks. However, in its implementation, not all funds collected from the community can be channeled properly and lending to the public often experiences obstacles in repaying loans to banks, so banks will experience problem loans. In addition to third party funds there are also other factors that influence credit distribution, namely the level of bank capital adequacy.

\section{LITERATURE REVIEW}

\section{Liquidity Preference Theory}

Liquidity Preference Theory (liquidity desire theory), which was originally developed by (J.M. Keynes, 1946) analyzes the equilibrium interest rate through the interaction of the money supply with the public aggregate demand for holding money. Keynes assumes that most individuals hold wealth in only two forms: money and bonds. According to Keynes, money is equivalent to currencies and demand deposits, which pay no interest or pay very low interest, but are very liquid and can be used for transactions. The liquidity preference theory is based on the demand and supply of money supply and the view that all financial decisions emphasize the money aspect of liquidity.

Therefore the loan fund model is developed based on the flow of funds in the financial system and views financial decisions as made with a broader principle of liquidity. Historically interest rates are almost as old as human civilization, in other words interest rates have been around for a long time. This is consistent with the opinion expressed by (Modigliani, 1944) which states that people have borrowed goods from others and sometimes they have asked for compensation for services rendered. The rewards are called rent, which is the price of borrowing someone else's property. Whereas Tobin (1958) states that interest is the amount of funds, valued from money, received by the lender (the creditor), while the interest rate is the ratio of interest to the loan amount. So the interest rate is the price of borrowing money to use purchasing power. Interest rates are one of the variables in the economy that is always closely 
watched because of its broad impact. Interest directly affects people's daily lives and has an important impact on the health of the economy in terms of consumption, credit, bonds, and savings.

Financial intermediation is the key to understanding why profits are supervised by an intermediary which is not carried out by the depositor (Diamond, Douglas W, 1984). Financial intermediation allows the best contracts and large allocations as a positive role in the financial intermediation process. In general loans and deposits without high leverage result in a low probability of default (default). However, with the model of monitoring and diversifying the increase in lending and savings the possibility of default remains low. Diamond (1984) developed a theory of financial intermediation on moral hazard, where the presence of banks as delegated monitoring can reduce the monitoring costs of the customer (investor) to the borrower (borrower). The efficiency resulting from this mechanism will make it easier for borrowers to minimize costs when producing. Capital providers will delegate to banking to monitor borrowers. Therefore, the bank will examine all current activities and future prospects of the debtor to protect depositors and shareholders.

\section{Financial Intermediation Theory}

A number of other theories include Allen and Santomero (1997), Bikker et al. (2003), further said that why banks, and financial intermediaries in general can exist because they can mitigate the liquidity risk arising from the flow of funds from a surplus party (depositor) by becoming an agent against those who need funds (borrowers). The risk arises because of the occurrence of asymmetric information, contracting costs, and scale mismatches between the liquidity of the fund and the liquidity of the parties that need funds. The basic theory of intermediation from financial intermediary institutions is to see banks as solutions to these problems, because banks have a comparative advantage about all information about the crediting values of debtors (Pyle, 1971), (Scholes et al., 1976) banks are better able to monitor debtors than Individual creditors (Leland and Pyle, 1977), banks can provide greater liquidity than funds collected from the household sector and business sector and can issue demand deposits that can be exchanged for funds (Fama, 1980).

\section{Agency Theory}

Agency theory is a contract between the owner (principal) and manager (agent) (Michael et al., 1976). The proper contract planning between the owner and manager to equalize the interests is the core problem of agency theory. Agency theory is based on several assumptions (Eisenhardt, 1989). These assumptions are assumptions about human nature, organizational assumptions, information assumptions. The assumption of human nature emphasizes that humans have selfishness and do not want to take risks. Organizational assumptions emphasize conflicts between members of the organization. Information assumption is that information is a commodity that can be traded. Michael et al. (1976) in the company's daily activities involved some parties who seemed to be mutually binding cooperation contracts to achieve common goals. They are shareholders, managers, employees, suppliers, and users who play roles in their interests and hope that the other party will act in accordance with what was agreed upon. Here we see the rational behavior that lies behind the framework of the principal agent's relationship. The relationship between agents and principals 
basically arises because there is a pattern of management of a company organization that separates owners (shareholders) from managers (managers). Shareholders act as principals who give the highest authority to run the company to managers who act as agents. The assumption is that the agent will act on behalf of and fully in the interests of shareholders. This pattern is common when companies grow and develop. It can no longer be managed like a small company where the owner can double as a manager.

\section{Hypothesis}

Njuguna and Tabhita (2015) Company liquidity is the main determinant of a company's profitability. Liquidity is the amount of capital available for investment and expenditure. Capital includes cash, credit and equity. Most capital is credit rather than cash. The relationship between bank liquidity as measured by a loan to deposit ratio (LDR) with profitability on return on assets (ROA) has been examined in banks in Europe with significant positive results (Bourke, 1989). This finding shows that the greater the amount of credit extended, the greater the interest income received by banks so that the return on assets increases. The results of this study also showed that the greater the source of idle bank funds (idle funds) the smaller the profitability.

Hypothesis 1: The loan to deposit ratio has a positive effect on return on assets.

Capital Adequacy Ratio (CAR) as an indicator of a bank's ability to cover a decline in assets as a result of losses suffered by banks, the size of the CAR is determined by the ability of banks to generate profits and the composition of funds allocated to assets according to their level of risk. 11/3 / DPNP dated January 27, 2009 concerning Calculation of Risk-Weighted Assets (ATMR) for Operational Risk Using the Basic Indicator Approach (PID) that the CAR ratio takes into account the credit risk, operational risk, and CAR market risk determined by Bank Indonesia is minimal 8\% as stated in BI Regulation Number 10/15 / PBI / 2008 Article 2 Paragraph 1 and line with standards set by the Bank of International Settlements (BIS).

Hypothesis 2: Capital adequacy ratio has a positive effect on return on assets.

The liquidity ratio aims to assess the company's financial ability to meet its short-term obligations and financial payment commitments. The higher the liquidity ratio, the better it will be for investors. Companies that have high liquidity ratios will be of interest to investors and will also impact on stock prices that tend to rise due to high demand. The increase in stock prices indicates an increase in company performance and this will also have an impact on investors because they will get a high rate of return on their investment. (Cinzia Baldan *, 2012), (Putranto et al., 2014), (Jara-Bertin et al., 2014), (Petria et al., 2015), (Owoputi et al., 2014).

Hypothesis 3: Raroc can mediate LDR against ROA

Capital adequacy is a policy or regulation of a company or banking in handling its capital. Capital is funds invested by the owner in the context of establishing a business entity that is intended to finance the bank's business activities in addition to meeting regulations set by the monetary authority (Hrishikes Bhattacharya, 2013). Adequate capital can increase public confidence, because it indicates that banks can accommodate the possibility of loss risk that will be experienced by banks due to bank operational activities. That way, capital adequacy will have an impact on increasing profits or profitability of banks through loan interest. CAR is an indicator that is often used to measure the level of bank capital adequacy. 
Hypothesis 4: Raroc can mediate CAR against ROA

Credit risk can be in the form of sovereign risk (risk), this risk arises when a country imposes foreign exchange control (foreign exchange control) so that it becomes impossible for other parties to pay off their obligations. Default risk is company risk, while the sovereign risk is country risk. Another form of credit risk is settlement risk that arises when two payments in foreign currencies are made on the same day, this risk occurs when the counterparty (the other party) may experience a default after the institution makes payments. On settlement, the amount of the default counterparty loss (the other party) is equal to the full value to be paid. While the amount of exposure before the settlement is only the net value of the two payments. Hypothesis 5: Raroc has a negative effect on Return On Assets.

\section{RESEARCH METHODS}

\section{Samples and Data}

The object of this research is the banking companies listed on the stock exchange from 2010 to 2018. The type of data in this documentary is data in the form of financial statements of banking companies in Indonesia for the period 2010-2018. For the source of the data is secondary data, that is data obtained from other parties, in this case the data source is the Indonesian stock exchange in the form of financial reports (annual report) at the address www.idx.co.id. and Bloomberg. Data using panel/pooling data, combined time series data with cross-section data so that a large sample can be obtained.

\section{Operational Variable Independent Variable}

Bank Liquidity that can carry out the intermediation function is a bank that can collect savings funds and then distribute it in the form of credit in a balanced manner or banking terms is the bank has a loan to deposit ratio (LDR) according to the target. The LDR of banks that are on target for commercial banks in Indonesia is a minimum of 78 percent and a maximum of 92 percent (Bank Indonesia, 2013). Liquidity in this study was proxied by LDR (Schmaltz, 2009), (Shen et al., 2009), (Arif and Nauman Anees, 2012), (Imbierowicz and Rauch, 2014), (Alzorqan, 2014), (Foran and O ', Sullivan, 2014),

$$
\text { LDR }=\text { (total loans) } / \text { (third party funds) } \mathrm{x} 100 \% \text { Independent variable }
$$

Capital Adequacy, Banks are required to provide a minimum capital of $8 \%$ of riskweighted assets (RWA). For banks that own or exercise control over the company. The said obligation applies to banks individually and banks in consolidation with companies. To anticipate losses according to the risk profile, BI can require banks to provide a minimum capital of more than 8 percent of RWA. This is due to the assessment of capital factors based on the ratio of Capital to Risk-Weighted Assets (ATMR). Khaled A. Zedan (2017) Anshika (2016), Ezike and Oke (2013) use CAR measurements for capital adequacy. Capital factor valuation is measured using the Capital Adequacy Ratio (CAR) with the following formula:

$\mathrm{CAR}=($ Bank Capital $) /($ Risk Weighted Assets $) \times 100 \%$ 


\section{Dependent Variable}

Financial ratios are ratios compiled from financial data obtained from the income statement or statement of financial position (balance sheet) or both. By using financial ratios, it can be seen the level of liquidity, profitability or solvency of the company. Financial ratios also have predictive power to predict the likelihood of a company's failure (Whittington*, 1980). Financial ratios can be used to determine the performance of a company in an industry, company performance from one time to another time, as well as company performance compared to predetermined criteria, measurement of bank performance using data based on financial statements called financial performance (Gibson, 2005 ) Return on assets (ROA) is the most widely used and most popular profitability ratio to measure a company's financial performance and to find out the company's prospects in the future. Bank profitability or profitability is the ability of banks to generate profits, one of which is the return on assets, which is calculated by comparing earnings before tax and total assets (Bank Indonesia 2011). Return on assets (ROA) measures bank management in order to utilize physical resources and financial resources from banks to generate returns (Wall, 1987).

\section{Mediation Variable}

$$
\text { ROA }=(\text { Profit Before Tax }) /(\text { Total Assets }) \times 100 \%
$$

Raroc (return adjusted risk on capital) is a tool in risk management in the rank of testing a credit risk in the context of risk management in a bank. Raroc was popularized by the Bankers Trust since 1979 which was then followed and used by various banks. According to Zaik et al. (1996) required risk measurement with reasons for the purpose of risk management determining how much each transaction contributed to total bank risk.

\section{Raroc $=($ Adjusted Income $) /($ Capital at Risk)}

Where, Adjusted Income is adjusted to equal net profit after interest and taxes (income spread + operating costs-tax). Capital at risk is usually set at the same size as an unexpected loss. Research using Raroc (Kupiec, 2001), (MCGuire, 1999), (Ieraci, 2009).size, this dissertation research follows, (Zhou \& Lao, 2012), (Ahmed S. Alanazi et al., 2011) (Mnif. 2010), which uses Ln total assets for Company Size.

\section{RESULT AND DISCUSSION}

Table 1. The Results of The Path Coefficient and P-Value

\begin{tabular}{lrr}
\hline Path Description & Path Koefisien & P-Value \\
\hline LDR $\rightarrow$ ROA & 0.174 & $<0.001$ \\
CAR $\rightarrow$ ROA & -0.063 & $<0.001$ \\
LDR $\rightarrow$ RAROC & -0.028 & 0.321 \\
CAR $\rightarrow$ RAROC & -0.200 & 0.002 \\
RAROC $\rightarrow$ ROA & 0.323 & 0.147 \\
\hline
\end{tabular}

The first hypothesis testing results show that liquidity has a positive effect on bank performance, this is indicated by a coefficient value of 0.174 and p-value $<0.001$, so that the first hypothesis is accepted. For testing the second hypothesis, capital adequacy has a positive effect on bank performance with a coefficient of -0.063 and $p$-value $<0.001$ consistent with the 
hypothesis so that this hypothesis is accepted. Furthermore, the third hypothesis is that credit risk can mediate liquidity on bank performance, with a coefficient of -0.200 and p-value 0.002 , so this third hypothesis is rejected, but its influence is accepted in line with the hypothesis. The fourth hypothesis is that credit risk can mediate capital adequacy on bank performance, where the coefficient value is 0.323 and p-value is 0.147 , this hypothesis is accepted however. And then the fifth hypothesis of credit risk has a negative effect on bank performance with a coefficient of -0.0.28 and a p-value of 0.321 then this hypothesis is accepted but not significant. The sixth hypothesis is that interest rate risk has a negative effect on bank performance, where the coefficient value is 0.106 and the p-value is 0.039 , which means that it is significant at 3 percent, so this hypothesis is accepted.

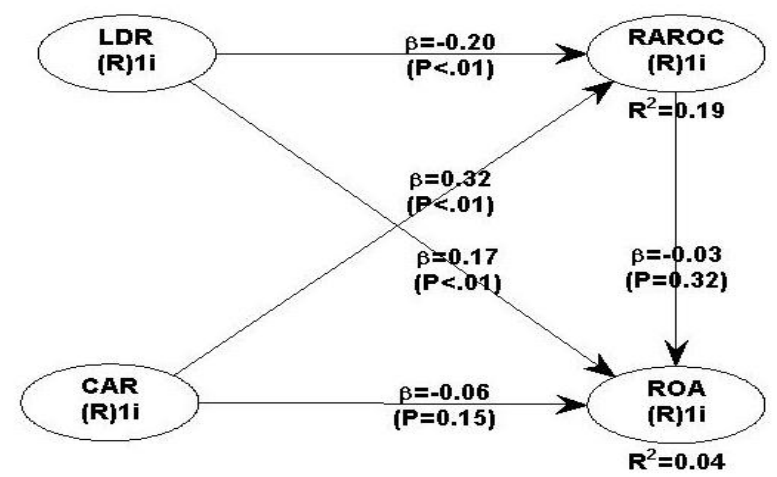

Figure 1. Full Model Image

\section{CONCLUSION}

Based on the results of testing and analysis with WarpPLS 5.0, we get the following conclusions: credit risk which is proxied by Raroc can mediate liquidity on bank performance, this is in line with several theories relating to liquidity management, among others: Commercial loan theory: the theory emphasizes that banks should only provide loans or short-term loans that are nature productive and can have the ability to repay loans (self liquidating) Shiftability theory, this theory is based on the ability of banks to exchange some form of wealth with other forms to meet liquidity. The doctrine of anticipated income, according to this theory, it is important that the loan will be paid back or it will not be determined by the income that is expected to be obtained from activities that are either directly financed with the loan or indirectly.

\section{REFERENCES}

Ahmad, R. (2016). A Study of Relationship between Liquidity and Profitability of Standard Charterd Bank Pakistan: Analysis of Financial Statement Approach. Global Journal of Management And Business Research. 
Allen, F., dan A. M. Santomero. (1997). The Theory of Financial Intermediation". Journal of Banking \& Finance, 21(11), 1461-1485.

Alzorqan, S. (2014). Bank Liquidity Risk and Performance: An Empirical Study of The Banking System in Jordan. Research Journal of Finance and Accounting, 5 (12).

Arif, A., dan A. Nauman Anees. (2012). Liquidity Risk and Performance of Banking System. Journal of Financial Regulation and Compliance, 20 (2), 182-195.

Bikker, J. A., S. Wesseling, dan P. J. A. Els. (2003). Intermediation, integration and internationalisation: a survey on banking in Europe: De Nederlandsche Bank.

Bourke, P. (1989). Concentration and Other Determinants of Bank Profitability in Europe, North America and Australia. Journal of Banking \& Finance, 13 (1), 65-79.

Cornett, M. M., J. J. McNutt, P. E. Strahan, dan H. Tehranian. (2011). Liquidity Risk Management and Credit Supply in The Financial Crisis. Journal of financial Economics, 101 (2), 297-312.

Diamond, D. W. (1984). Financial Intermediation and Delegated Monitoring. The Review of Economic Studies, 51 (3), 393-414.

eisenhardt, k. (1989). Agency Theory an Assessment And Review. academy of management review, Vol. 14, No., hlm: 57-74.

Ezike, J. E., dan M. O. Oke. (2013). Capital Adequcy Stabndars, Basle Accord and Bank Peformance : Nigerian Experience (Studi Case Selected Banks In Nigeria). Asian Economic and Financial Review.

Fama, E. F. (1980). Banking in The Theory of Finance". Journal Of Monetary Economics, 6, (1), 39-57.

Foran, J., dan N. O'Sullivan. (2014). Liquidity Risk and The Performance of UK Mutual Funds. International Review of Financial Analysis, 35, 178-189.

Gambacorta, L., dan H. S. Shin. (2016). Why Bank Capital Matters For Monetary Policy. Journal of Financial Intermediation, Vol., No., hlm.

Garr, D. K. (2013). Determinants of Credit Risk in The Banking Industry Of Ghana. Developing Country Studies, 3 (11), 2225-0565.

Gibson, H. D. (2005). Greek Banking Profitability: Recent Developments.

Handorf, W. C. (2014). The Cost Of Bank Liquidity. Journal of Banking Regulation, 15 (1), 113.

Hrishikes Bhattacharya. (2013). Capital Regulation and Rising Risk of Banking Industry; a Financial Accounting Perspective. Academy of Banking Studies Journal, 12.

Ieraci, R. (2009). Enterprise Risk-RAROC: A Tool For Factoring Risk Into Investment, Pricing, and Compensation-Models of Risk-Adjuster Return on Capital Offer Advantages To Banks, But Interpreting Them Requires Extreme Care. RMA Journal, $91(6), 68$.

Imbierowicz, B., dan C. Rauch. (2014). The Relationship Between Liquidity Risk And Credit Risk in Banks. Journal of Banking \& Finance, 40, 242-256.

Jara-Bertin, M., J. Arias Moya, dan A. Rodriguez Perales. (2014). Determinants of Bank Performance: Evidence For Latin America. Academia Revista Latinoamericana de Administración, 27 (2), 164-182.

Khaled A. Zedan, G. D. (2017). Palestinian Banks Analysis Using CAMEL Model. 
Kupiec, P. (2001). Estimating Credit Risk Capital: What's the Use?. The Journal of Risk Finance, 2 (3), 17-34.

Leland, H. E., dan D. H. Pyle. (1977). Informational Asymmetries, Financial Structure, and Financial Intermediation. The Journal of Finance, 32 (2), 371-387.

Marozva, G. (2015). Liquidity and Bank Performance. The International Business \& Economics Research Journal (Online), 14 (3), 453.

MCGuire, C. (1999). RAROC on the Rise. Wall Street \& Technology, 17 (9), 44-44.

Michael, C. Jensen, dan Meckling. (1976). Theory Of The Firm: Managerial Behavior Agency Costs Nad Ownership Structure. Financial Economics, 3, 305-360.

Modigliani, F. (1944). Liquidity Preference and The Theory of Interest and Money. Journal of the Econometric Society

Njuguna, dan Tabhita. (2015). Effect of Liquidity Management On Profitability.

Olagunju, A., A. David, dan O. O. Samuel. (2012). Liquidity Management and Commercial Banks' Profitability in Nigeria. Research Journal of Finance and Accounting, 2, 24-38.

Owoputi, J. A., O. F. Kayode, dan F. A. Adeyefa. (2014). Bank Specific, Industry Specific and Macroeconomic Determinants of Bank Profitability in Nigeria. European Scientific Journal, 10 (25).

Petria, N., B. Capraru, dan I. Ihnatov. (2015). Determinants Of Banks' Profitability: Evidence From EU 27 Banking Systems. Procedia Economics and Finance, 20, 518-524.

Putranto, A., A. Herwany, dan E. Sumirat. (2014). The Determinants of Commercial Bank Profitability In Indonesia.

Pyle, D. H. (1971). On The Theory of Financial Intermediation. The Journal of Finance, 26 (3), 737-747.

Saci, K., G. Giorgioni, dan K. Holden. (2009). Does Financial Development Affect Growth?". Applied Economics, 41 (13), 1701-1707.

Schmaltz, C. (2009). Liquidity Management. A Quantitative Liquidity Model for Banks: Springer, 75-131.

Scholes, M., G. J. Benston, dan C. W. Smith. (1976). A Transactions Cost Approach to The Theory of Financial Intermediation. The Journal of Finance, 31 (2), 215-231.

Tobin, J. (1958). Liquidity Preference as Behavior Towards Risk. The Review of Economic Studies, 25 (2), 65-86.

Vuong Thao Tran, C.-T. L., Hoa Nguyen. (2016). Liquidity Creation, Regulatory Capital, and Bank Profitability.

Zaik, E., J. Walter, G. Retting, dan C. James. (1996). RAROC at Bank of America: From Theory to Practice". Journal of Applied Corporate Finance, 9 (2), 83-93. 